\title{
Investigation of surface roughness and material removal rate for UD-GFRP composite using Taguchi grey relational analysis
}

\author{
Surinder $\operatorname{Kumar}^{1 *}$ and Meenu ${ }^{2}$ \\ ${ }^{1}$ Department of Mechanical Engineering, \\ National Institute of Technology, Kurukshetra 136119, India \\ *Email: surinder.asd@gmail.com \\ ${ }^{2}$ Department of Mechanical Engineering, \\ National Institute of Technology, Kurukshetra 136119, India \\ Email: meenu_1625@ymail.com
}

\begin{abstract}
In this paper, a grey relational method was used for minimising surface roughness and maximising material removal rate during turning of unidirectional glass fibre reinforced plastic composite (UD-GFRP). Taguchi approach was used for the experiment. The parameters studied were tool rake angle, speed, depth of cut, feed, tool nose radius, and cutting environment. Castrol water (1:6) miscible soluble coolant was flooded in the machining zone. Cutting environment: Wet $\left(33^{\circ}-38^{\circ} \mathrm{c}\right)$ and Cold $\left(5^{\circ}-7^{\circ} \mathrm{c}\right)$ were used. The Taguchi $\mathrm{L}_{18}$ orthogonal array was used for performing the experiment. Significant parameters were found by applying ANOVA. The grey relational analysis was used to optimise the parameters affecting the response. Cutting speed was the factor, followed by feed rate that influenced surface roughness and material removal rate. The surface roughness of $1.761 \mu \mathrm{m}$ and material removal rate of $275.78 \mathrm{~mm}^{3}$ were achieved.
\end{abstract}

Keywords: UD-GFRP; material removal rate; surface roughness; grey relational analysis; Taguchi method; Carbide cutting tool.

\section{INTRODUCTION}

The development of composite materials began to accelerate when thermosetting resin systems with useful mechanical and adhesive properties became available between the two World Wars. When glass fibre became commercially available around the time of the Second World War, it could be combined with these resin systems to produce the first modern composite; glass fibre reinforced plastic. Although the use of carbon fibres was growing rapidly glass fibre is still by far the most commonly used reinforcement material in fibre reinforced plastics. In 2006, approximately 163000 metric tons of fibres were used worldwide in the manufacture of composites with E-glass fibre making up $80 \%$ of this total [1-5]. The main reason that glass fibre is very dominant in the market is that it comparatively incurs low cost. Analysis of data revealed that the average cost of carbon fibre is approximately 26 times greater per unit mass than that of E-glass fibre. The density of E-glass fibre is significantly higher than that of carbon fibre and so the cost per unit volume is even greater. In modern-day, components made of fibre-reinforced plastics are in great demand. In corrosive industrial applications, fibreglass composites are an alternative to stainless steel and other materials [6,7]. GFRP is used in various products including sporting goods, marine bodies, plastic pipes, storage containers, and 
construction works. In transport industry, these are widely used [8]. The machining of GFRP composites is dissimilar from conventional materials and it necessitates special considerations on wear resistance of the tool [2]. Surface unevenness of a product could affect its functional attributes such as friction, wear, light reflection, transmission of heat, and capability for lubrication [2]. In order to get the fine surface finish and dimensional properties, it requires techniques to find the best possible cutting parameters and theoretical models for predictions [9]. The behaviour of FRP during machining is different from metals because it depends on the fibre and matrix properties, type of weave, and fibre orientation [10]. A statistical technique was used by Aravindan et al. [11] to investigate the machinability of hand lay-up GFRP pipes. The surface finish of 4 to 8 microns was achieved whereas surface roughness was 80 to 100 microns using an unmachined surface.

Parveen Raj et al. [12] used response surface methodology roughness and artificial neural network to model surface roughness and delamination during the machining of GFRP using coated and uncoated K10 cutting tools. Four parameters considered were tool material, feed rate, cutting speed, and depth of cut (DOC). It was found that artificial neural network (ANN) due to its good interpolation capability can be used to model effectively. The performance of coated tool with good surface finish was better than uncoated tool. Behera et al. [13] investigated the effect of cutting speed, depth of cut, and feed on the cutting force while turning GFRP using HSS tool. The depth of cut was found to be the most significant followed by feed rate. Varghese et al. [14] used Al oxide ceramic inserts to optimise the parameters in turning of GFRP. The depth of cut, speed, length of the tool from tool holder, and feed rate were the parameters selected. Taguchi method was used for experimentation while grey relation was used for analysis. It was found that the moderate feed rate, minimum tool length, and moderate depth of cut gave optimal results. Hussain et al. [15] investigated the turning process of glass fibre reinforced plastic composite using Taguchi's technique and fuzzy logic. Carbide (K20) cutting tool was used for turning while four parameters such as cutting speed, fibre orientation angle, depth of cut, and feed rate were selected. Taguchi method combination with fuzzy logic resulted in low cutting force, surface roughness, cutting power, and specific cutting pressure in machining GFRP composites using carbide K20 cutting tool. Surface methodology and genetic algorithm were also used by Hussain et al. [16] to optimise parameters during turning of GFRP. It was observed that the quality of the surface improved when response surface method was used in combination with genetic algorithm. Polycrystalline diamond (PCD) cutting tool was used for turning while four parameters such as cutting speed, fibre orientation angle, depth of cut, and feed rate were selected. Parida and Routara [17] developed a material removal rate and surface roughness prediction model for the machining of glass fibre reinforced plastic composite using Taguchi's technique and TOPSIS method by using a carbide tool. Three parameters such as cutting speed, feed rate, and depth of cut were selected. It was observed that there was a good agreement between the estimated value and experimented value using TOPSIS method for multi-response. Parida et al. [18] developed a material removal rate and surface roughness prediction model for the machining of glass fibre reinforced plastic composite using Taguchi's technique and grey relational analysis by using the cemented carbide tool. Three parameters such as cutting speed, feed rate, and depth of cut were selected. The depth of cut followed by feed rate and spindle speed was found to be the significant parameter for surface roughness. Surinder Kumar et al. [19] used a distancebased Pareto genetic algorithm in combination with Taguchi's techniques to find the optimum parameters required for turning GFRP. PCD cutting tool was used for turning 
and six parameters such as tool nose radius, tool rake angle, cutting speed, feed rate, cutting environment, and depth of cut were selected. It was observed that production rates increased considerably by reducing machining time. Meenu and Surinder Kumar [20] used the grey relation analysis to find the optimum parameters in the turning of GFRP. The cutting force was used as response characteristics. The depth of cut followed by tool nose radius was found to be the most influential factor for the minimisation of tangential, feed, and radial forces in turning process. Surinder Kumar et al. [21] developed a surface roughness and delamination mathematical prediction model for the machining of unidirectional glass fibre reinforced plastic composite using multiple regression analyses and genetic algorithm by using the carbide (K10) cutting tool. It was observed that the single response algorithms based on efficient methodology; a genetic algorithm was utilised to optimise machining parameters in the machining of UD-GFRP. From the ANOVA result, it was concluded that feed rate, cutting speed, and depth of cut have a significant effect on surface roughness. It was found that feed rate was more significant than other parameters; whilst depth of cut was the least significant parameter.

Meenu and Surinder Kumar [22]developed surface roughness prediction model for the machining of unidirectional glass fibre reinforced plastics composite using ANN. PCD cutting tool was used for turning and six parameters such as tool nose radius, tool rake angle, cutting speed, feed rate, cutting environment, and depth of cut were selected. The performance of the model was found to be good with the mean percentage error of 2.0506 and feasibility of using ANN to predict surface roughness. The regression coefficient was found to be more than 0.9. Raveendran and Marimuthu [23] optimised the surface roughness and tool wear rate by using the grey relation analysis. It was concluded that the depth of cut followed by feed rate was a significant factor surface roughness while the depth of cut followed by cutting speed was the significant factor for tool wear. Amitesh Goswami and Jatinder Kumar [24] optimised surface roughness and material removal rate of Nimonic 80A using the wire electrical discharge machining (WEDM) process. Taguchi's approach and utility concept were used. Six parameters such as pulseon time, pulse-off time, spark gap set voltage, peak current, wire feed, and wire tension were selected to minimise the surface roughness and maximise the material removal rate. It was found that the optimised value of material removal rate (MRR) and surface roughness $(\mathrm{Ra})$ were pulse-on time $(118 \mathrm{~ms})$, pulse-off time $(30 \mathrm{~ms})$, input current $(80$ A), wire feed (10), wire tension (11) (1500 g) and spark gap set voltage $(50 \mathrm{~V})$. Subrahmanyam and Sarcar [25] proposed an approach for wire electrical discharge machining of a $\mathrm{H} 13$ hot die steel using the grey-based Taguchi technique. Eight process parameters such as voltage TON, TOFF, IP, SV WF, WT, SF, and WP were selected to minimise the surface roughness and maximise the material removal rate. It was found that the grey-Taguchi method was ideal and suitable for the parametric optimisation of the wire-cut EDM process when using the multiple performance characteristics such as material removal rate and surface roughness for machining the $\mathrm{H} 13$ or for the matter for any other material. Meenu and Surinder Kumar [26] used the grey relation analysis to find the optimum parameters in the turning of unidirectional GFRP composites. The surface roughness and material removal rate were used as response characteristics. The grey relation analysis was used to optimise the parameters while the principal component analysis was used for finding the relative significance of performance characteristics. The depth of cut was the factor, which has great influence on surface roughness and material removal rate followed by feed rate. 
Table 1. Summarised literature review.

\begin{tabular}{|c|c|c|c|c|c|}
\hline $\begin{array}{l}\text { Year } \\
\text { /Author }\end{array}$ & $\begin{array}{c}\text { Cutting } \\
\text { Tool } \\
\text { Materials }\end{array}$ & $\begin{array}{c}\text { Input } \\
\text { Parameters }\end{array}$ & $\begin{array}{c}\text { Output } \\
\text { Responses }\end{array}$ & Techniques & $\begin{array}{l}\text { Researcher's } \\
\text { Findings }\end{array}$ \\
\hline $\begin{array}{l}\text { Behera et al. } \\
{[7]}\end{array}$ & HSS tool & $\begin{array}{l}\text { speed, feed, } \\
\text { DOC }\end{array}$ & $\begin{array}{l}\text { Cutting } \\
\text { force and } \\
\text { Ra }\end{array}$ & $\begin{array}{l}\text { Single } \\
\text { objective } \\
\text { using } \\
\text { Taguchi's } \\
\text { technique }\end{array}$ & $\begin{array}{l}\text { It was found that the } \\
\text { depth of cut is the } \\
\text { most significant } \\
\text { parameter for cutting } \\
\text { force followed by } \\
\text { feed rate. }\end{array}$ \\
\hline $\begin{array}{l}\text { Varghese et } \\
\text { al. [8] }\end{array}$ & $\begin{array}{l}\text { Uncoated } \\
\text { aluminum } \\
\text { oxide } \\
\text { ceramic } \\
\text { inserts }\end{array}$ & $\begin{array}{l}\text { speed, feed, } \\
\text { DOC, tool } \\
\text { holder }\end{array}$ & $\begin{array}{l}\text { Cutting } \\
\text { force and } \\
\text { Ra }\end{array}$ & $\begin{array}{l}\text { Single } \\
\text { objective } \\
\text { using } \\
\text { Taguchi's } \\
\text { technique and } \\
\text { Grey based } \\
\text { method }\end{array}$ & $\begin{array}{l}\text { It was found that the } \\
\text { moderate feed rate, } \\
\text { minimum tool length } \\
\text { and moderate depth } \\
\text { of cut gave optimal } \\
\text { results. }\end{array}$ \\
\hline $\begin{array}{l}\text { Parida and } \\
\text { Routara [11] }\end{array}$ & Carbide tool & $\begin{array}{l}\text { speed, feed, } \\
\text { DOC }\end{array}$ & $\begin{array}{l}\mathrm{MRR} \text { and } \\
\mathrm{Ra}\end{array}$ & $\begin{array}{l}\text { Single } \\
\text { objective } \\
\text { using } \\
\text { Taguchi's } \\
\text { technique and } \\
\text { TOPSIS } \\
\text { method }\end{array}$ & $\begin{array}{l}\text { It was observed that } \\
\text { there is a good } \\
\text { agreement between } \\
\text { the estimated value } \\
\text { and the experimented } \\
\text { value using TOPSIS } \\
\text { method for multi } \\
\text { response. }\end{array}$ \\
\hline $\begin{array}{l}\text { Parida et al. } \\
\text { [12] }\end{array}$ & $\begin{array}{l}\text { Cemented } \\
\text { carbide tool }\end{array}$ & $\begin{array}{l}\text { speed, feed, } \\
\text { DOC }\end{array}$ & $\begin{array}{l}\text { MRR and } \\
\mathrm{Ra}\end{array}$ & $\begin{array}{l}\text { Single } \\
\text { objective } \\
\text { using } \\
\text { Taguchi's } \\
\text { technique and } \\
\text { GRA }\end{array}$ & $\begin{array}{l}\text { It was observed that } \\
\text { depth of cut is the } \\
\text { most significant } \\
\text { parameter for surface } \\
\text { roughness followed } \\
\text { by feed rate and } \\
\text { spindle speed for } \\
\text { multiple performance } \\
\text { characteristics. }\end{array}$ \\
\hline $\begin{array}{l}\text { Naveen Sait } \\
\text { et al. [26] }\end{array}$ & $\begin{array}{l}\text { Coated } \\
\text { carbide tool } \\
\text { (K20 grade) }\end{array}$ & $\begin{array}{l}\text { speed, feed, } \\
\text { DOC }\end{array}$ & $\begin{array}{l}\text { Ra, flank } \\
\text { wear, crater } \\
\text { wear and } \\
\text { cutting } \\
\text { force }\end{array}$ & $\begin{array}{l}\text { Single } \\
\text { objective } \\
\text { using } \\
\text { Taguchi's } \\
\text { technique and } \\
\text { desirability } \\
\text { function } \\
\text { analysis }\end{array}$ & $\begin{array}{l}\text { It was concluded that } \\
\text { the depth of cut is the } \\
\text { significant machining } \\
\text { parameter followed } \\
\text { by cutting velocity } \\
\text { and feed rate for } \\
\text { machining filament } \\
\text { wound GFRP pipes. }\end{array}$ \\
\hline $\begin{array}{l}\text { Davim and } \\
\text { Mata [27] }\end{array}$ & PCD & speed, feed & $\begin{array}{l}\text { Surface } \\
\text { roughness }\end{array}$ & $\begin{array}{l}\text { Single } \\
\text { objective } \\
\text { using } \\
\text { Taguchi's } \\
\text { technique and } \\
\text { Statistical } \\
\text { analysis }\end{array}$ & $\begin{array}{l}\text { It was found that the } \\
\text { feed rate is the cutting } \\
\text { parameter that has the } \\
\text { highest physical as } \\
\text { well statistical } \\
\text { influence on surface } \\
\text { roughness } \\
\text { workpiece. }\end{array}$ \\
\hline
\end{tabular}


Table 1. Continued

\begin{tabular}{|c|c|c|c|c|c|}
\hline $\begin{array}{l}\text { Year } \\
\text { /Author }\end{array}$ & $\begin{array}{c}\text { Cutting } \\
\text { Tool } \\
\text { Materials }\end{array}$ & $\begin{array}{c}\text { Input } \\
\text { Parameters }\end{array}$ & $\begin{array}{c}\text { Output } \\
\text { Responses }\end{array}$ & Techniques & $\begin{array}{l}\text { Researcher's } \\
\text { Findings }\end{array}$ \\
\hline Lee [28] & $\begin{array}{l}\text { Single } \\
\text { crystal } \\
\text { diamond, } \\
\text { Poly crystal } \\
\text { diamond } \\
\text { and CBN }\end{array}$ & $\begin{array}{l}\text { speed, feed, } \\
\text { DOC and } \\
\text { nose radius }\end{array}$ & $\begin{array}{l}\text { Ra, cutting } \\
\text { force and } \\
\text { power } \\
\text { spectrum } \\
\text { density }\end{array}$ & $\begin{array}{l}\text { Single } \\
\text { objective }\end{array}$ & $\begin{array}{l}\text { It was found that the } \\
\text { surface roughness } \\
\text { does not depend on } \\
\text { depth of cut and } \\
\text { cutting speed. }\end{array}$ \\
\hline $\begin{array}{l}\text { Kini et al. } \\
{[29]}\end{array}$ & $\begin{array}{l}\text { Coated } \\
\text { tungsten } \\
\text { carbide }\end{array}$ & $\begin{array}{l}\text { speed, feed, } \\
\text { DOC and } \\
\text { tool nose }\end{array}$ & $\begin{array}{ll}\mathrm{Ra} & \text { and } \\
\mathrm{MRR} & \end{array}$ & $\begin{array}{l}\text { Single } \\
\text { objective } \\
\text { using } \\
\text { Taguchi's } \\
\text { technique }\end{array}$ & $\begin{array}{l}\text { It was found that the } \\
\text { feed rate is main } \\
\text { factor that influence } \\
\text { the surface roughness, } \\
\text { followed by the depth } \\
\text { of cut. For material } \\
\text { removal rate, depth of } \\
\text { cut is main influence } \\
\text { factor followed by the } \\
\text { tool nose radius. } \\
\text { Cutting fluid used was }\end{array}$ \\
\hline $\begin{array}{l}\text { Sakuma and } \\
\text { Seto [30] }\end{array}$ & $\begin{array}{l}\text { Cemented } \\
\text { carbide tools } \\
\text { P20, M10, } \\
\text { K10 }\end{array}$ & $\begin{array}{l}\text { speed, feed, } \\
\text { DOC tool } \\
\text { material and } \\
\text { cutting fluid }\end{array}$ & $\begin{array}{l}\text { Ra and tool } \\
\text { wear in } \\
\text { facing test }\end{array}$ & $\begin{array}{l}\text { Single } \\
\text { objective }\end{array}$ & $\begin{array}{l}\text { (Wl-1) of } 3 \% \\
\text { concentration and } \\
\text { flow rate } 1.51 / \mathrm{min} \text {, } \\
\text { which was used to } \\
\text { wash out chips. }\end{array}$ \\
\hline $\begin{array}{l}\text { Palanikumar } \\
\text { et al. [31] }\end{array}$ & $\begin{array}{l}\text { Carbide } \\
\text { (K10) tool }\end{array}$ & $\begin{array}{l}\text { speed, feed, } \\
\text { DOC, } \\
\text { machining } \\
\text { time and } \\
\text { workpiece } \\
\text { fiber } \\
\text { orientation }\end{array}$ & $\begin{array}{l}\text { Ra, specific } \\
\text { cutting } \\
\text { pressure } \\
\text { and MRR }\end{array}$ & $\begin{array}{l}\text { Grey relation } \\
\text { analysis and } \\
\text { Single } \\
\text { objective } \\
\text { using } \\
\text { Taguchi's } \\
\text { technique }\end{array}$ & $\begin{array}{l}\text { It was concluded that } \\
\text { the work piece is the } \\
\text { factor which has great } \\
\text { influence on } \\
\text { machining of GFRP } \\
\text { composites, followed } \\
\text { by machining time. }\end{array}$ \\
\hline
\end{tabular}

Amitesh Goswami and Jatinder Kumar [26] investigated on surface integrity, material removal rate, and wire wear ratio of Nimonic 80A using WEDM process. Taguchi's design of experiment methodology was used. [27]. Six parameters such as pulse-on time, pulse-off time, spark gap set voltage, peak current, wire feed, and wire tension were selected. It was found that the recast layer was observed to increase with an increase in pulse-on time and peak current. Amitesh Goswami and Jatinder Kumar [26] optimised on material removal rate, surface roughness, and wire wear ratio of Nimonic 80A using WEDM process. Taguchi's approach and GRA concept were used. Four parameters such as pulse-on time, pulse-off time, peak current, and wire off-set were selected to minimise the wire wear ratio, and surface roughness and maximise the material removal rate. It was found that the value of MRR, Ra, and Wire off-set were pulse-on time $(0.60 \mathrm{ls})$, pulse-off time (14 ls), peak current (60A), and wire off-set $(0.08 \mathrm{~mm})$. The trim cut was also potential for the high surface finish compared to rough cut machining. Surinder Kumar et al. [27] reported a review of literature which showed that various evolutionary techniques in optimising machining process parameters positively gave good results. Based on the literature survey performed, the venture into this research is 
amply motivated by the fact that very few research works have been conducted to obtain the optimal levels of machining parameters that yield the best machining quality of unidirectional GFRP composite. Most of the researchers have investigated the influence of a limited number of process parameters on the performance measures of turning process. Literature revealed that response surface methodology and Taguchi method are the robust design techniques widely used in industries for making the product/process insensitive to any uncontrollable factors such as environmental variables. Thus, in this study, carbide (K10) cutting tool was used for turning pultruded UD-GFRP rods in dry, wet, and cool conditions. The experiments were intended based on Taguchi's $\mathrm{L}_{18}$ orthogonal array by predetermined cutting conditions. The considering parameters of tool nose radius, tool rake angle, cutting speed, feed rate, cutting environment, and depth of cut were optimised with multiple-response using a GRA approach with an aim to minimise surface roughness and maximise material removal rate. The GRA was used to find the optimum process parameters.

\section{METHODS AND MATERIALS}

\section{Work Material}

The work material used for the present investigation was UD-GFRP composite rods. The workpiece of $840 \mathrm{~mm}$ length and $42 \mathrm{~mm}$ diameter was used as shown in Figure 1(a). The pultrusion processed UD-GFRP composite rods consisting of epoxy resin and E-glass as the fibre was used. The UD-GFRP composite rod after machining is shown in Figure 1(b).
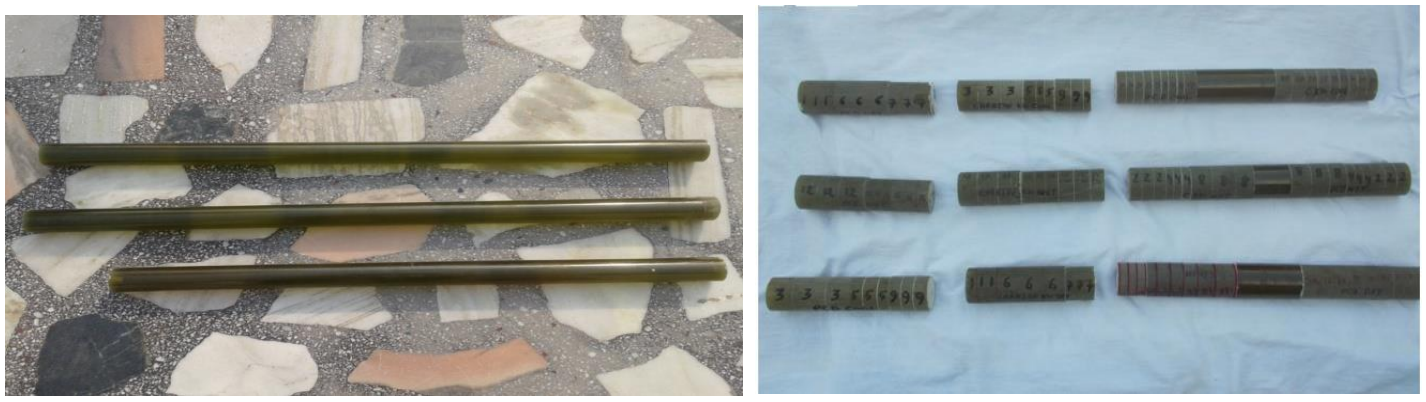

Figure 1. UD-GFRP composite rod specimens (a) before machining (b) after machining.

\section{Experimental setup}

NH22 lathe of make HMT, $11 \mathrm{~kW}$ spindle power, and a maximum speed of $3000 \mathrm{rpm}$ was used for the experimentation as shown in Figure 2. The cutting tool was inserted with two tool nose radius of 0.4 and $0.8 \mathrm{~mm}$ and three rake angles of $-6^{\circ}, 0^{\circ}$, and $+6^{\circ}$ were used. A tool holder made of steel EN47 was used. To ascertain the surface roughness and material removal rate, the experimental results of turning of UD-GFRP were evaluated. Carbide (K10) inserts used were of NQA BS EN ISO 9001-2000 coding VNMG 110404, VNMG 110408 as shown in Figure in 2(a) and 2(b). Tokyo Seimitsu Surfcom 130A type instrument shown in Figure 2 was used for measuring surface roughness. The cut-off length of $0.8 \mathrm{~mm}$ with a transverse length of $4 \mathrm{~mm}$ was used. 


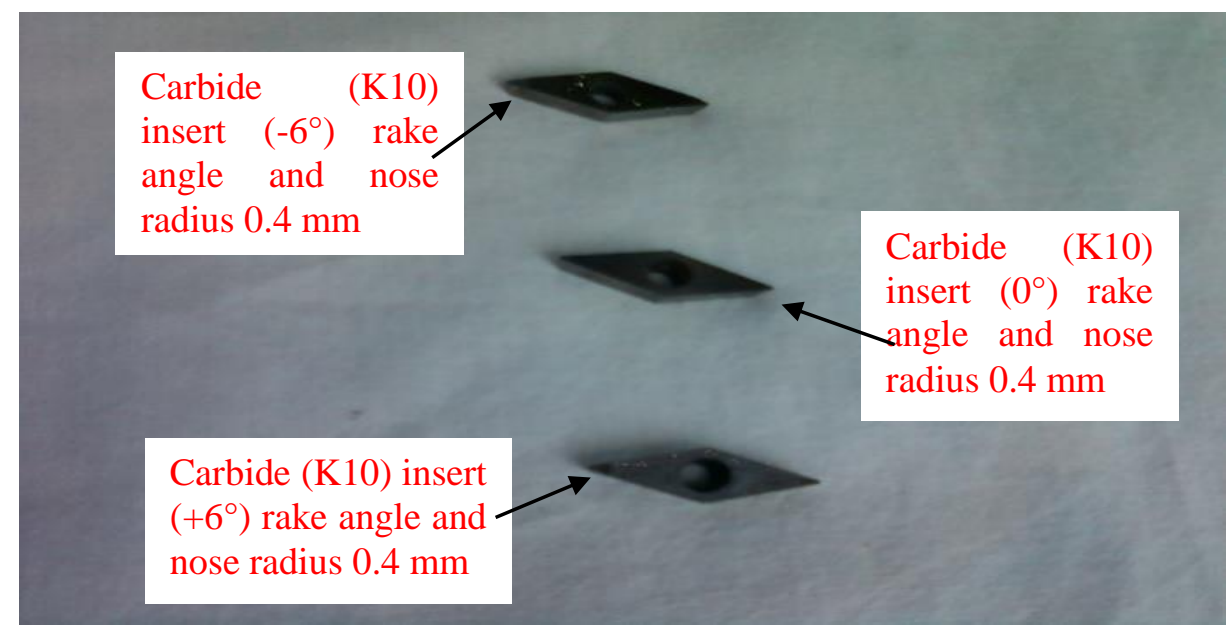

(a) Nose radius $0.4 \mathrm{~mm}$

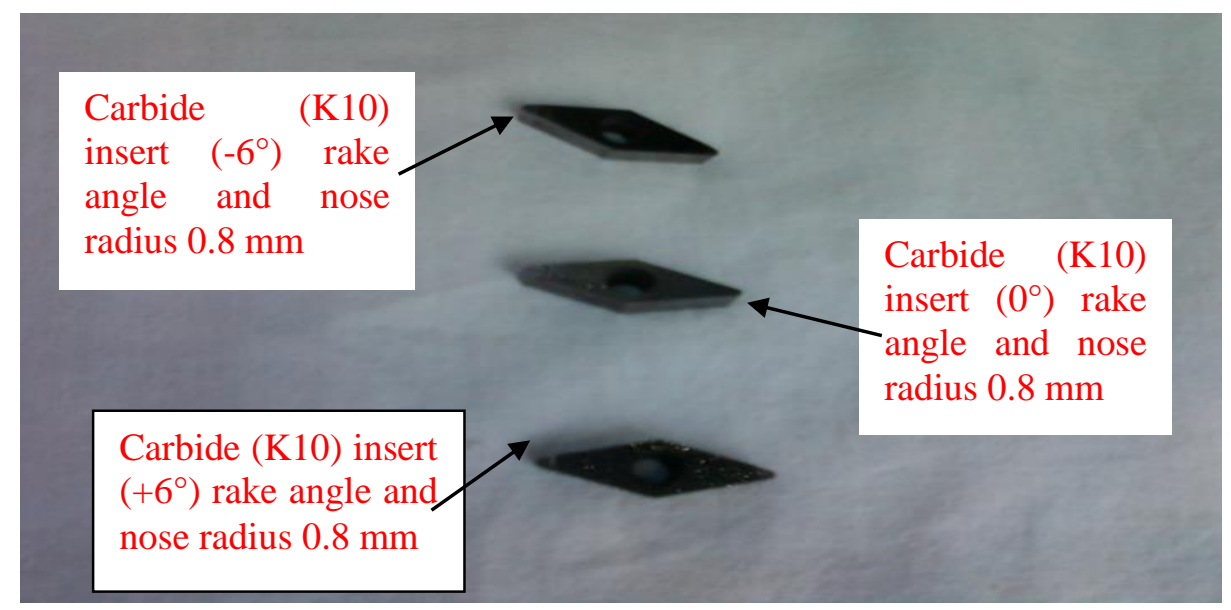

(b) Nose radius $0.8 \mathrm{~mm}$

Figure: 2. Carbide (K10) cutting tool used in the experiment.

\section{Machining Parameter Selection}

In this study, one parameter at a time approach was used to select the parameters. The experimental plan had tool nose radius, tool rake angle, feed rate, cutting speed, cutting environment, and depth of cut as the controllable variables. As there were two levels of tool nose radius, Taguchi's mixed level design was selected. The number of degree of freedom for tool nose radius was 1 and number of degree of freedom for other five parameters was 2 . Hence, the total number of the degree of freedom for one-two level parameter and five-three level parameters were $\left(1 * 1+(5 * 2)\right.$. Thus, an $\mathrm{L}_{18}$ orthogonal array with 17 degrees of freedom was selected. Parameters were assigned to columns using linear graphs. The unassigned columns represented an error. The ranges of the parameter were given in Table 2 . Table 3 shows the $L_{18}$ orthogonal array employed for the experimentation. 
Table 2. Process parameters with different operating levels.

\begin{tabular}{lccc}
\hline \multicolumn{1}{c}{ Input Variables } & \multicolumn{3}{c}{ Levels } \\
\cline { 2 - 4 } & 1 & 2 & 3 \\
\hline Nose Radius / mm & 0.4 & 0.8 & - \\
Rake angle / Degree & -6 & 0 & +6 \\
Feed / (mm/rev.) & 0.05 & 0.1 & 0.2 \\
Speed / (m/min.) \& rpm & $(55.42) 420$ & $(110.84) 840$ & $(159.66) 1210$ \\
Cutting environment & Dry & Wet & Cooled \\
Depth of cut / mm & 0.2 & 0.8 & 1.4 \\
\hline
\end{tabular}

Table 3. O. A. $\mathrm{L}_{18}$ of Taguchi along with assigned value.

\begin{tabular}{ccccccc}
\hline $\begin{array}{c}\text { Expt. } \\
\text { No. }\end{array}$ & $\begin{array}{c}\text { Nose } \\
\text { Radius (A) }\end{array}$ & $\begin{array}{c}\text { Rake } \\
\text { Angle }(\mathrm{B})\end{array}$ & $\begin{array}{c}\text { Feed } \\
(\mathrm{C})\end{array}$ & $\begin{array}{c}\text { Speed } \\
(\mathrm{D})\end{array}$ & $\begin{array}{c}\text { Cutting } \\
\text { Environment (E) }\end{array}$ & $\begin{array}{c}\text { Depth of } \\
\text { Cut (F) }\end{array}$ \\
\hline 1 & 0.4 & $-6^{\circ}$ & 0.05 & $(55.42) 420$ & Dry & 0.2 \\
$\mathbf{2}$ & 0.4 & $-6^{\circ}$ & 0.1 & $(110.84) 840$ & Wet & 0.8 \\
3 & 0.4 & $-6^{\circ}$ & 0.2 & $(159.66) 1210$ & Cooled & 1.4 \\
4 & 0.4 & $0^{\circ}$ & 0.05 & $(55.42) 420$ & Wet & 0.8 \\
$\mathbf{5}$ & 0.4 & $0^{\circ}$ & 0.1 & $(110.84) 840$ & Cooled & 1.4 \\
6 & 0.4 & $0^{\circ}$ & 0.2 & $(159.66) 1210$ & Dry & 0.2 \\
7 & 0.4 & $+6^{\circ}$ & 0.05 & $(110.84) 840$ & Dry & 1.4 \\
8 & 0.4 & $+6^{\circ}$ & 0.1 & $(159.66) 1210$ & Wet & 0.2 \\
9 & 0.4 & $+6^{\circ}$ & 0.2 & $(55.42) 420$ & Cooled & 0.8 \\
10 & 0.8 & $-6^{\circ}$ & 0.05 & $(159.66) 1210$ & Cooled & 0.8 \\
11 & 0.8 & $-6^{\circ}$ & 0.1 & $(55.42) 420$ & Dry & 1.4 \\
12 & 0.8 & $-6^{\circ}$ & 0.2 & $(110.84) 840$ & Wet & 0.2 \\
13 & 0.8 & $0^{\circ}$ & 0.05 & $(110.84) 840$ & Cooled & 0.2 \\
14 & 0.8 & $0^{\circ}$ & 0.1 & $(159.66) 1210$ & Dry & 0.8 \\
15 & 0.8 & $0^{\circ}$ & 0.2 & $(55.42) 420$ & Wet & 1.4 \\
16 & 0.8 & $+6^{\circ}$ & 0.05 & $(159.66) 1210$ & Wet & 1.4 \\
17 & 0.8 & $+6^{\circ}$ & 0.1 & $(55.42) 420$ & Cooled & 0.2 \\
18 & 0.8 & $+6^{\circ}$ & 0.2 & $(110.84) 840$ & Dry & 0.8 \\
\hline
\end{tabular}

\section{RESULTS AND DISCUSSION}

Table 4 shows the various results of the surface roughness and material removal rate as per designed $\mathrm{L}_{18}$ orthogonal array. ANOVA was performed by using MINITAB 16 software. The results of ANOVA surface roughness and material removal rate are shown in Tables 5 and 6, respectively.

\section{Single Response Optimisation}

Mean performance and confidence interval for predicted mean were found by Taugchi's approach. The confirmation experiments were performed three times while the average value was reported as $\mu_{\mathrm{Ra}}$ representing the optimum surface roughness at selected process parameters. The optimum parameters selected were C2, D2, and F1. The estimated mean of the response characteristic can be computed as [28]:

$$
\mu_{R a}=\overline{T_{R a}}+\left(\overline{C 2}-\overline{T_{R a}}\right)+\left(\overline{D 2}-\overline{T_{R a}}\right)+\left(\overline{F 1}-\overline{T_{R a}}\right)
$$


where $\overline{T_{R a}}=$ overall mean of surface roughness $=2.272$ microns; $\overline{C 2}=1.976$ microns, $\overline{D 2}=2.006$ microns, $\bar{F} 1=1.947$ microns; Hence, $\mu_{R} a=1.385$ microns.

A confidence interval for the predicted mean on a confirmation run can be calculated using Equation 2 [24]:

$$
C I_{C E}=\sqrt{F_{a}\left(1, f_{e}\right) V_{e}\left[\frac{1}{n_{e f f}}+\frac{1}{R}\right]}
$$

where $\mathrm{F} \alpha ;(1, \mathrm{fe})=\mathrm{F}_{0.05} ;(1 ; 42)=4.08$ (tabulated); $\alpha=0 \cdot 05, f_{e}=$ error $\mathrm{DOF}=42, N=18$; $n_{\text {eff }}=$ effective number of replications.

Table 4. Experimental data of Ra and MRR.

\begin{tabular}{|c|c|c|c|c|c|c|c|c|}
\hline \multirow{4}{*}{$\begin{array}{l}\text { Expt. } \\
\text { No. }\end{array}$} & \multicolumn{4}{|c|}{ Responses } & \multicolumn{4}{|c|}{ Responses } \\
\hline & \multicolumn{3}{|c|}{ Raw Data } & \multirow{3}{*}{$\begin{array}{l}\text { Average } \\
\operatorname{Ra}(\mu \mathrm{m})\end{array}$} & \multicolumn{3}{|c|}{ Raw Data } & \multirow{3}{*}{$\begin{array}{c}\text { Average } \\
\text { MRR } \\
\left(\mathrm{mm}^{3} / \mathrm{sec}\right)\end{array}$} \\
\hline & \multicolumn{3}{|c|}{$\begin{array}{l}\text { Surface Roughness } \\
\qquad(\mu \mathrm{m})\end{array}$} & & \multicolumn{3}{|c|}{$\begin{array}{l}\text { Material Removal Rate } \\
\left(\mathrm{mm}^{3} / \mathrm{sec}\right)\end{array}$} & \\
\hline & $\mathrm{R} 1$ & R2 & R3 & & & $\mathrm{R} 2$ & R3 & \\
\hline 1 & 1.59 & 1.65 & 1.49 & 1.577 & 8.50 & 8.60 & 8.70 & 8.60 \\
\hline 2 & 1.73 & 1.77 & 1.99 & 1.830 & 144.96 & 145.02 & 145.02 & 145.00 \\
\hline 3 & 2.77 & 4.12 & 5.13 & 4.00 & 329.98 & 330.23 & 330.23 & 330.15 \\
\hline 4 & 2.20 & 2.18 & 2.04 & 2.140 & 36.24 & 36.24 & 36.24 & 36.24 \\
\hline 5 & 1.83 & 1.83 & 1.77 & 1.810 & 237.96 & 237.90 & 238.04 & 237.97 \\
\hline 6 & 2.69 & 2.88 & 2.89 & 2.820 & 99.00 & 98.90 & 98.93 & 98.93 \\
\hline 7 & 1.62 & 1.94 & 2.12 & 1.893 & 125.03 & 125.02 & 125.02 & 125.02 \\
\hline 8 & 1.99 & 1.79 & 1.89 & 1.890 & 52.98 & 52.95 & 52.99 & 52.97 \\
\hline 9 & 2.58 & 2.94 & 2.10 & 2.540 & 144.92 & 145.02 & 144.90 & 144.95 \\
\hline 10 & 2.90 & 2.72 & 2.35 & 2.656 & 104.39 & 104.41 & 104.39 & 104.40 \\
\hline 11 & 2.15 & 2.20 & 1.95 & 2.100 & 124.96 & 124.96 & 124.96 & 124.96 \\
\hline 12 & 2.45 & 1.56 & 2.26 & 2.090 & 73.54 & 73.53 & 73.51 & 73.53 \\
\hline 13 & 1.77 & 1.55 & 1.89 & 1.736 & 18.39 & 18.39 & 18.38 & 18.39 \\
\hline 14 & 3.05 & 2.41 & 2.51 & 2.656 & 197.70 & 197.06 & 197.92 & 197.56 \\
\hline 15 & 2.61 & 1.87 & 3.38 & 2.620 & 240.94 & 241.06 & 240.92 & 240.97 \\
\hline 16 & 2.26 & 2.69 & 1.96 & 2.303 & 170.00 & 170.09 & 170.00 & 170.03 \\
\hline 17 & 1.65 & 1.68 & 1.38 & 1.570 & 18.38 & 18.38 & 18.39 & 18.38 \\
\hline 18 & 2.53 & 2.99 & 2.50 & 2.673 & 261.00 & 260.93 & 260.80 & 260.91 \\
\hline
\end{tabular}

$\mathrm{n}_{\mathrm{eff}}=\mathrm{N} / 1+[$ Total DOF associated in the estimate of mean $]=4.5$

$\mathrm{Ve}=0.1717$

Hence, putting all the values in Eq. (1)

$C I_{C E}= \pm 0.624$

The $95 \%$ confidence interval for $\mu \mathrm{Ra}$ is,

$\left[\mu_{R a}-C I\right]<\mu_{R a}<\left[\mu_{R a}+C I\right]$

$0.761<\mu_{R a}$ (microns) $<2.009$ 
Similarly, for MMR,

$$
\text { HMRR }=\overline{T_{M R R}}+\left(\overline{C 3}-\overline{T_{M R R}}\right)+\left(\overline{D 3}-\overline{T_{M R R}}\right)+\left(\overline{F 3}-\overline{T_{M R R}}\right)
$$

where $\overline{T_{M R R}}=132.72 \mathrm{~mm}^{3} / \mathrm{sec} ; \overline{C 3}=191.57 \mathrm{~mm}^{3} / \mathrm{sec}$., $\overline{D 3}=159.01 \mathrm{~mm}^{3} / \mathrm{sec} ., \overline{F 3}=$ $204.85 \mathrm{~mm}^{3} / \mathrm{sec}$; Hence $\mu M R R=289.99 \mathrm{~mm}^{3} / \mathrm{sec}$.

$\mathrm{Ve}=983 ; C I_{C E}= \pm 47.179$

The $95 \%$ confidence interval for $\mu \mathrm{MMR}$ is,

$\left[\mu_{M R R}-C I\right]<\mu_{M R R}<\left[\mu_{M R R}+C I\right]$

$242.811<\mu_{\text {MRR }}\left(\mathrm{mm}^{3} / \mathrm{sec}.\right)<337.169$

Tables 7 and 8 show the predicted optimum value and confirmatory experimental results, respectively. The mean values of the three experiments conducted for confirmation were found to be within the confidence intervals.

Table 5. Analysis of variance (mean value) for Ra.

\begin{tabular}{lccccccc}
\hline \multicolumn{1}{c}{ Source } & SS & DOF & V & F ratio & Prob. & SS $^{\prime}$ & P (\%) \\
\hline Nose radius (A) & 0.0017 & 1 & 0.0017 & Pooled & 0.922 & --- & --- \\
Rake angle (B) & 0.4989 & 2 & 0.2495 & Pooled & 0.245 & -- & --- \\
Feed (C) & 7.3151 & 2 & 3.6575 & $21.30^{*}$ & 0.000 & 6.972 & 29.110 \\
Speed (D) & 5.5154 & 2 & 2.7577 & $16.06^{*}$ & 0.000 & 5.172 & 21.595 \\
Cutting Environment (E & 0.5283 & 2 & 0.2641 & Pooled & 0.227 & --- & --- \\
Depth of cut (F) & 2.8789 & 2 & 1.4394 & $8.38^{*}$ & 0.001 & 2.535 & 10.584 \\
& & & & & & & \\
$\mathrm{~T}$ & 23.9501 & 53 & & & & 23.9501 & 100.00 \\
$\mathrm{e}$ (pooled) & 7.2119 & 42 & 0.1717 & & & 9.1010 & 37.99 \\
\hline $\mathrm{SS}$
\end{tabular}

$\mathrm{SS}=$ sum of squares, $\mathrm{DOF}=$ degrees of freedom, variance $(\mathrm{V})=(\mathrm{SS} / \mathrm{DOF}), \mathrm{T}=$ total, $\mathrm{SS}^{\prime}$ $=$ pure sum of squares, $\mathrm{P}=$ percent contribution, $\mathrm{e}=$ error, $\mathrm{F}_{\text {ratio }}=(\mathrm{V} /$ /error $)$, Tabulated $\mathrm{F}-$ ratio at $95 \%$ confidence level $\mathrm{F}_{0.05 ; 1 ; 42}=4.08, \mathrm{~F}_{0.05 ; 2 ; 42}=3.23$, * Significant at $95 \%$ confidence level

Table 6 Analysis of variance (mean value) for MRR

\begin{tabular}{lccccccc}
\hline \multicolumn{1}{c}{ Source } & SS & DOF & V & F ratio & Prob. & SS $^{\prime}$ & P (\%) \\
\hline Tool Nose radius (A) & 143 & 1 & 143 & Pooled & 0.705 & --- & --- \\
Tool rake angle (B) & 906 & 2 & 453 & Pooled & 0.634 & --- & --- \\
Feed rate (C) & 118198 & 2 & 59099 & $60.10^{*}$ & 0.000 & 116232 & 26.377 \\
Cutting speed(D) & 39209 & 2 & 19605 & $19.94^{*}$ & 0.000 & 37243 & 8.452 \\
Cutting Environment (E) & 4879 & 2 & 2440 & Pooled & 0.096 & --- & --- \\
Depth of cut (F) & 236028 & 2 & 118014 & $120.02^{*}$ & 0.000 & 234062 & 53.116 \\
& & & & & & & \\
Te (pooled) & 440662 & 53 & & & & 440662 & 100.00 \\
& 41300 & 42 & 983 & & & 52113 & 11.826 \\
\hline
\end{tabular}

$\mathrm{SS}=$ sum of squares, DOF $=$ degrees of freedom, variance $(\mathrm{V})=(\mathrm{SS} / \mathrm{DOF}), \mathrm{T}=$ total, $\mathrm{SS}^{\prime}=$ pure sum of squares, $\mathrm{P}=$ percent contribution, $\mathrm{e}=$ error, $\mathrm{F}_{\text {ratio }}=(\mathrm{V} / \mathrm{error})$, Tabulated F-ratio at $95 \%$ confidence level $\mathrm{F}_{0.05 ; 1 ; 42}=4.08, \mathrm{~F}_{0.05 ; 2 ; 42}=3.23$, * Significant at $95 \%$ confidence level. 
Table 7. Single response results.

\begin{tabular}{llll}
\hline Method & Characteristic & Optimal condition & $\begin{array}{l}\text { Optimal } \\
\text { predicted value }\end{array}$ \\
\hline Single response & Ra & A2B3C2D2E2F1 & $1.385 \mathrm{microns}$ \\
& MRR & A2B2C3D3E3F3 & $289.99 \mathrm{~mm}^{3} / \mathrm{sec}$.
\end{tabular}

Table 8. Confirmatory experimental results.

\begin{tabular}{lcclc}
\hline Response (units) & Predicted & Experimental & \multicolumn{1}{c}{ CI $_{\mathrm{CE}}$} & Percentage \\
\hline $\mathrm{Ra}($ microns) & 1.385 & 1.650 & $0.761<\mu_{\mathrm{Ra}}<2.009$ & 16 \\
$\mathrm{MRR}\left(\mathrm{mm}^{3} / \mathrm{sec}\right)$ & 289.99 & 328.11 & $242.811<\mu_{\mathrm{MRR}}<337.169$ & 11 \\
\hline
\end{tabular}

\section{Multi-response using the Grey Relational Analysis}

For multiple objectives of using GRA steps are to (a) conduct an experiment using orthogonal array, (b) normalise data, (c) calculate quality loss function, (d) calculate grey relational coefficient, and (e) use weighting approach to calculate the grey relational grade.

\section{Normalisation of Data}

In the grey relation method, data were to be normalised due to different dimensions and scope of data. To bring the data into $0-1$, the range linear normalisation was done. For normalisation used for surface roughness and MRR, Equations 5 and 6 were used, respectively. For Ra Lower the better

$$
x_{i}^{*}(k)=\frac{\operatorname{maxx}_{i}(k)-x_{i}(k)}{\max _{i}(k)-\min x_{i}(k)}
$$

For MRR Higher the better

$$
x_{i}^{*}(k)=\frac{x_{i}(k)-\min x_{i}(k)}{\max x_{i}(k)-\min x_{i}(k)}
$$

where, $\mathrm{n}$ and $\mathrm{m}$ represent the numbers of response variable $\mathrm{S}$ and experiments, respectively. Where $\mathrm{x}_{\mathrm{i}}(\mathrm{k})$ is the original sequence of the surface roughness and material removal rate, $\mathrm{x}_{\mathrm{i}}{ }^{*}(\mathrm{k})$ is the comparable sequence after data normalisation, $\max \mathrm{x}_{\mathrm{i}}(\mathrm{k})$ and min $x_{i}(k)$ are the largest and smallest values of $x_{i}(k)$, respectively. In this paper, $m=18, n$ $=2$ were taken.

\section{Calculation of Quality Loss Function}

Quality loss function $\Delta_{o i}(\mathrm{k})$ is calculated by Equation 7 where $\mathrm{x}_{\mathrm{o}}{ }^{*}(\mathrm{k})=1$.

$$
\Delta_{o i}(\mathrm{k})=\mathrm{x}_{\mathrm{o}}^{*}(\mathrm{k})-\mathrm{x}_{\mathrm{i}}^{*}(\mathrm{k})
$$




\section{Calculation of Grey Relational Coefficient}

The grey relational coefficient is calculated [25] as given in Eq. (8).

$$
\gamma\left(x_{o}^{*}(k), x_{i}^{*}(k)\right)=\frac{\Delta_{\min }+\zeta \cdot \Delta_{\max }}{\Delta_{\mathrm{oi}}(\mathrm{k})+\zeta \cdot \Delta_{\max }}
$$

$\zeta$ a distinguishing coefficient was set at 0.5 . The range of which was 0-1.

$$
\begin{gathered}
\Delta_{\min }=\min _{\forall_{\mathrm{i}}} \min \Delta_{o i}(\mathrm{k}) \\
\Delta_{\mathrm{max}}=\max _{\forall_{\mathrm{i}}} \max _{o i} \Delta_{\mathrm{k}}(\mathrm{k})
\end{gathered}
$$

$(\Delta \mathrm{Ra}) 01=1-0.997=0.003$

$(\Delta \mathrm{MRR}) 01=1-0.000=1.000$

From the data in Table 9, the following is achieved:

$\Delta_{\max }=\Delta 03(\mathrm{Ra})=\Delta 01(\mathrm{MRR})=1.000$,

$\Delta_{\min }=\Delta 17(\mathrm{Ra})=\Delta 03(\mathrm{MRR})=0.000$,

The grey relational coefficient is calculated from the Equation (8) (Table 9). For example:

$\zeta_{1}(\mathrm{Ra})=[0.000+(0.5 \times 1.000)] /[0.003+(0.5 \times 1.000)]=0.994$

$\zeta_{1}(\mathrm{MRR})=[0.000+(0.5 \times 1.000)] /[1.000+(0.5 \times 1.000)]=0.333$

\section{Calculation of the Grey Relational Grade}

The grey relational grade is a weighted average of the grey relational coefficients, which indicate the level of correlation between the reference sequence and comparability sequence given by Equation (9).

$$
\Psi\left(x_{o}^{*}, x_{i}^{*}\right)=\sum_{k=1}^{n} \omega_{k} \gamma\left(x_{o}^{*}(k), x_{i}^{*}(k)\right)
$$

where $\omega_{\mathrm{k}}$ is the weight of the $\mathrm{k}^{\text {th }}$ performance characteristics and $\sum_{k=1}^{n} \omega_{k}=1$. By assigning the equal weighting values of $\mathrm{Ra}=0.5$ and $\mathrm{MMR}=0.5$, the GR grade was calculated (Table 9).

An $\mathrm{L}_{18}$ orthogonal array as shown in Table 3 was used to perform the experiments. Table 4 shows the experimental results. Table 9 shows the overall grey relational grade and $\mathrm{S} / \mathrm{N}$ ratio for eighteen experiments. A higher value of grey relation grade represents optimum combination of the parameters. The $\mathrm{S} / \mathrm{N}$ ratio for an overall grey relational grade is calculated using the higher the better criteria. Experiment 2 shows the high value of grey relation grade. The grey relational graph is plotted as shown in Figure 3. 
Table 9. Grey relational grade data.

\begin{tabular}{cccccccccc}
\hline No. & $\begin{array}{c}\text { Mean (Ra) } \\
\text { Normalised }\end{array}$ & $\begin{array}{c}\text { Mean } \\
\text { (MRR) } \\
\text { Normalised }\end{array}$ & $\Delta_{\text {Ra }}$ & $\Delta_{\text {MRR }}$ & $\begin{array}{c}\text { GR } \\
\text { coeff. } \\
\text { (Ra) }\end{array}$ & $\begin{array}{c}\text { GR } \\
\text { coeff. } \\
\text { (MRR) }\end{array}$ & $\begin{array}{c}\text { GR } \\
\text { Grade }\end{array}$ & $\begin{array}{c}\text { GR } \\
\text { grade } \\
\text { ratio }\end{array}$ & $\begin{array}{c}\text { GR } \\
\text { grade } \\
\text { Mean }\end{array}$ \\
\hline 1 & 0.997 & 0.000 & 0.003 & 1.000 & 0.994 & 0.333 & 0.664 & -3.559 & 0.664 \\
2 & 0.893 & 0.737 & 0.107 & 0.263 & 0.824 & 0.655 & 0.739 & -2.623 & 0.739 \\
3 & 0.000 & 1.000 & 1.000 & 0.000 & 0.333 & 1.000 & 0.667 & -3.522 & 0.667 \\
4 & 0.765 & 0.086 & 0.235 & 0.914 & 0.681 & 0.354 & 0.517 & -5.728 & 0.517 \\
5 & 0.901 & 0.713 & 0.099 & 0.287 & 0.835 & 0.636 & 0.735 & -2.670 & 0.735 \\
6 & 0.486 & 0.281 & 0.514 & 0.719 & 0.493 & 0.410 & 0.452 & -6.906 & 0.452 \\
7 & 0.867 & 0.362 & 0.133 & 0.638 & 0.790 & 0.439 & 0.615 & -4.227 & 0.615 \\
8 & 0.868 & 0.138 & 0.132 & 0.862 & 0.792 & 0.367 & 0.579 & -4.742 & 0.579 \\
9 & 0.601 & 0.424 & 0.399 & 0.576 & 0.556 & 0.465 & 0.510 & -5.842 & 0.510 \\
10 & 0.553 & 0.298 & 0.447 & 0.702 & 0.528 & 0.416 & 0.472 & -6.521 & 0.472 \\
11 & 0.782 & 0.362 & 0.218 & 0.638 & 0.696 & 0.439 & 0.568 & -4.916 & 0.568 \\
12 & 0.786 & 0.202 & 0.214 & 0.798 & 0.700 & 0.385 & 0.543 & -5.308 & 0.543 \\
13 & 0.932 & 0.030 & 0.068 & 0.970 & 0.880 & 0.340 & 0.610 & -4.293 & 0.610 \\
14 & 0.553 & 0.588 & 0.447 & 0.412 & 0.528 & 0.548 & 0.538 & -5.384 & 0.538 \\
15 & 0.568 & 0.723 & 0.432 & 0.277 & 0.536 & 0.643 & 0.590 & -4.586 & 0.590 \\
16 & 0.698 & 0.502 & 0.302 & 0.498 & 0.624 & 0.501 & 0.562 & -5.000 & 0.562 \\
17 & 1.000 & 0.030 & 0.000 & 0.970 & 1.000 & 0.340 & 0.670 & -3.477 & 0.670 \\
18 & 0.546 & 0.785 & 0.454 & 0.215 & 0.524 & 0.699 & 0.612 & -4.271 & 0.612 \\
\hline
\end{tabular}

Table 10. Response table for grey relational grade.

\begin{tabular}{|c|c|c|c|c|c|c|}
\hline Level & $\begin{array}{l}\text { Nose } \\
\text { radius }\end{array}$ & $\begin{array}{l}\text { Rake } \\
\text { angle }\end{array}$ & Feed & Speed & $\begin{array}{c}\text { Cutting } \\
\text { environment }\end{array}$ & $\begin{array}{c}\text { Depth of } \\
\text { cut }\end{array}$ \\
\hline 1 & 0.6087 & 0.6087 & 0.5733 & 0.5865 & 0.5746 & 0.5863 \\
\hline 2 & 0.5738 & 0.5736 & 0.6383 & 0.6423 & 0.5885 & 0.5647 \\
\hline 3 & & 0.5914 & 0.5621 & 0.5450 & 0.6107 & 0.6228 \\
\hline $\begin{array}{l}\text { Delta } \\
(\max -\min )\end{array}$ & 0.0349 & 0.0351 & 0.0762 & 0.0973 & 0.0362 & 0.0580 \\
\hline Rank & 6 & 5 & 2 & 1 & 4 & 3 \\
\hline
\end{tabular}

Table 11. Comparison of results.

\begin{tabular}{cccc}
\hline Method & Characteristic & Optimal condition & $\begin{array}{c}\text { Optimal } \\
\text { Experimental } \\
\text { value }\end{array}$ \\
\hline $\begin{array}{c}\text { Single response } \\
\text { Optimisation }\end{array}$ & $\begin{array}{c}\text { Surface Roughness } \\
\text { Material Removal Rate }\end{array}$ & $\begin{array}{c}\text { A2B3C2D2E2F1 } \\
\text { A2B2C3D3E3F3 }\end{array}$ & $\begin{array}{c}1.650 \mathrm{microns} \\
328.11 \mathrm{~mm}^{3} / \mathrm{sec} .\end{array}$ \\
$\begin{array}{c}\text { Multi response } \\
\text { optimisation (GRA) }\end{array}$ & $\begin{array}{c}\text { Surface Roughness } \\
\text { Material Removal Rate }\end{array}$ & A1B1C2D2E3F3 & $1.761 \mathrm{microns}^{275.78 \mathrm{~mm}^{3} / \mathrm{sec} .}$ \\
\hline
\end{tabular}




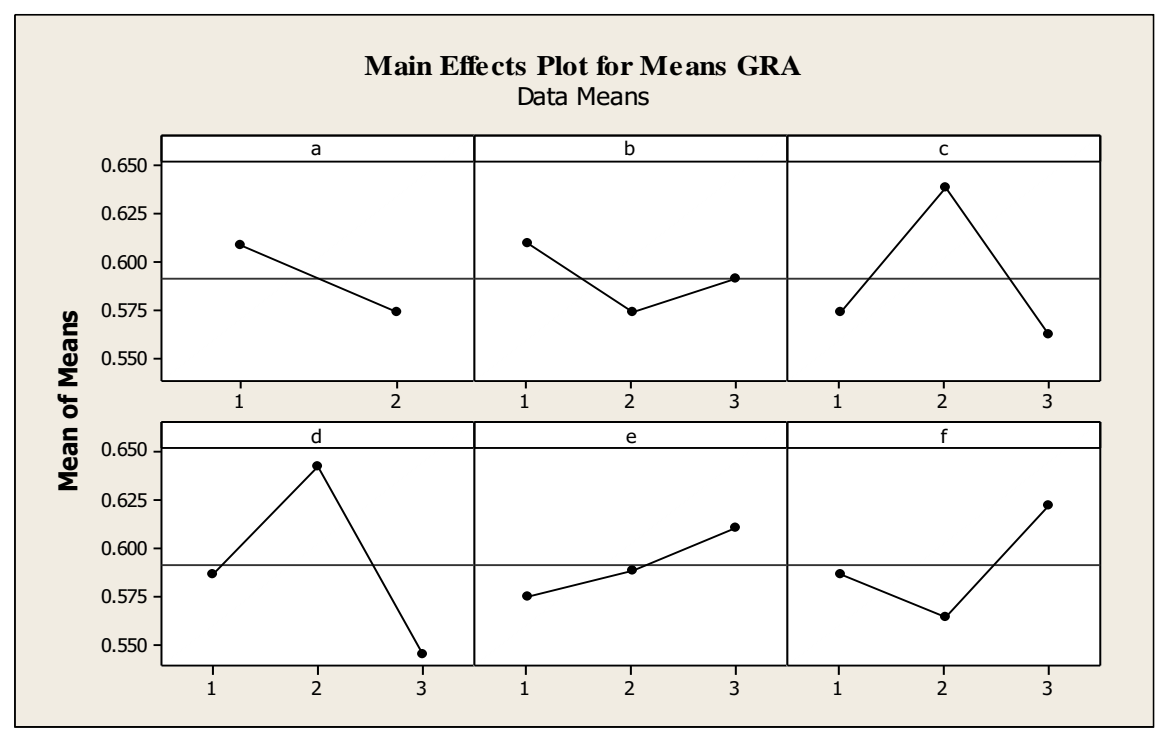

Figure 3. Effects of process parameters on Ra and MRR.

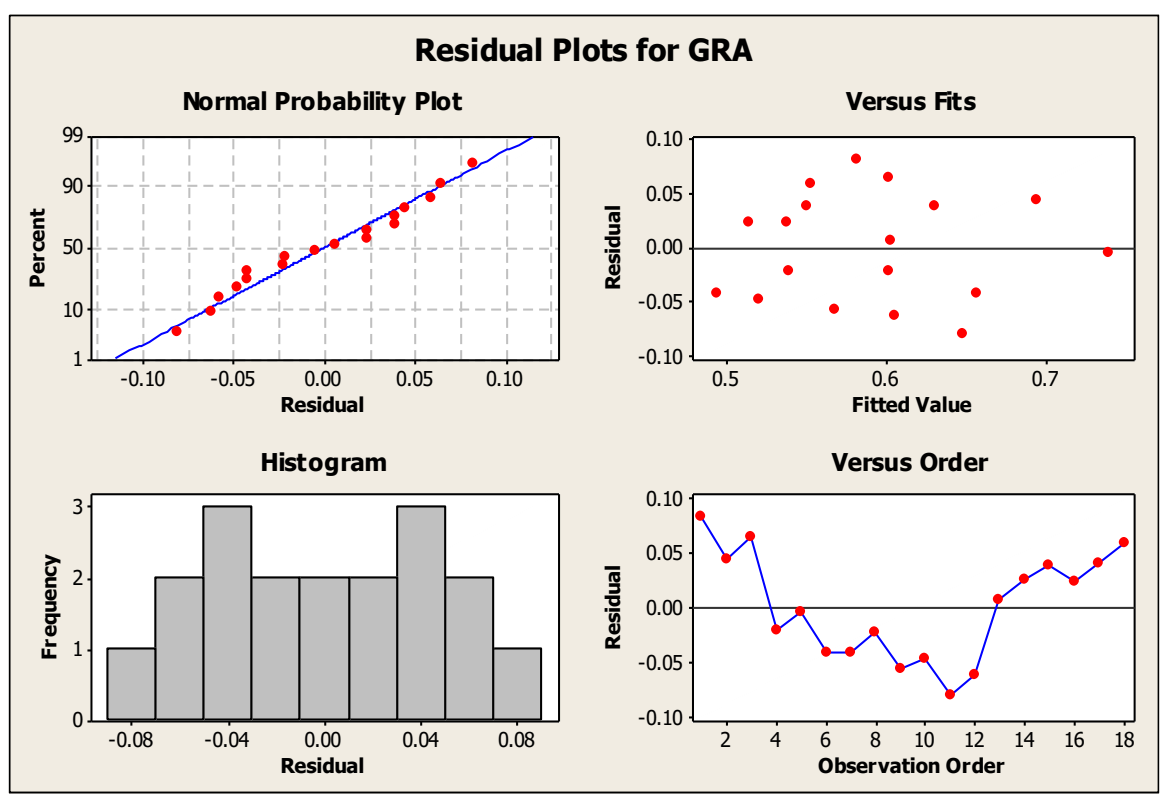

Figure 4. Residual plots for Ra and MRR (GRA Raw Data).

The mean value of grey relational grade was 0.5912. A1B1C2D2E3F3 representing the optimum process parameter. Therefore, A1B1C2D2E3F3 was the optimal parameter combination for two performance characteristics. The response table for the grey relation grade is given in Table 10. Therefore, the grade corresponding to the optimal level in this table is shown in bold. The table shows the optimal value as A1B1C2D2E3F3. Ranks were assigned based on $\Delta$ values which were the difference between the highest and lowest average of each factor. Rank 1 was the highest $\Delta$ value. The ranks indicate the relative importance of each factor to the response. The difference of raw data between level 1 and 3 indicates that cutting speed has the highest effect $(\Delta=$ $\max -\min =0.0973)$ followed by feed rate $(\Delta=\max -\min =0.0762)$ and depth of cut $(\Delta=$ $\max -\min =0.0580)$. Table 10 shows the comparison of results between the single response and multi-response optimisations using GRA. The standardised residuals were 
plotted on a normality plot to check the departure of the data from normality. Figure 3 shows the mean value of grey relation grade of Ra and MRR. Figure 4 shows the normal probability plot of residuals vs. the order of the data, plot of residuals vs. the fitted values for grey, and histogram residuals vs. fitted value. Figure 4(a) shows that the data were normal as all the points lied close to the straight line. No noticeable pattern was revealed by Figure 4 (b-d). The parallel table shows the comparison of the single and multiobjective results.

\section{CONCLUSIONS}

In the present study, Taguchi's Grey Relational technique was used to find the optimal process parameters. Experiments were performed according to Taguchi's $\mathrm{L}_{18}$ orthogonal array. Optimisation was performed by using the grey relation analysis during rough cutting unidirectional glass fibre reinforced plastics using carbide (K10) cutting tool. $\mathrm{A} 1 \mathrm{~B} 1 \mathrm{C} 2 \mathrm{D} 2 \mathrm{E} 3 \mathrm{~F} 3$ were found to be the optimum process parameter. From the ANOVA result, it was concluded that $\mathrm{C}$ - feed rate, D - cutting speed, $\mathrm{F}$ - depth of cut had a significant effect on surface roughness and material removal rate. $\mathrm{A}, \mathrm{B}$, and $\mathrm{E}$ had no effect at $95 \%$ confidence level. These levels were experimentally confirmed. The cutting speed followed by feed rate was found to be the significant parameters. The surface roughness of $1.761 \mu \mathrm{m}$ and MRR of $275.78 \mathrm{~mm}^{3}$ were achieved.

\section{ACKNOWLEDGMENTS}

The author acknowledged the financial support is given by the National Institute of Technology Kurukshetra through scholarship. The authors are also thankful to the Maharashtra Engineering Industry, India (P) Limited, Satara Maharashtra for supplying the UD- GFRP rods used in this work.

\section{REFERENCES}

[1] Roberts T. Rapid growth forecast for carbon fibre market. Reinforced Plastics. 2007;51:10-3.

[2] Taufik RS, Adibah M NF, Muhamad MR, Hasib H. Feasibility study of natural fiber composite material for engineering application. Journal of Mechanical Engineering and Sciences. 2014;6:940-8.

[3] Zakaria KA, Jimit RH, Ramli SNR, Aziz AA, Bapokutty O, Ali MB. Study on fatigue life and fracture behaviour of fibreglass reinforced composites. Journal of Mechanical Engineering and Sciences. 2016;10:2300-10.

[4] Fairuz AM, Sapuan SM, Zainudin ES, Jaafar CNA. Effect of filler loading on mechanical properties of pultruded kenaf fibre reinforced vinyl ester composites. Journal of Mechanical Engineering and Sciences. 2016;10:1931-42.

[5] Abdul Majid MS, Daud R, Afendi M, Amin NAM, Cheng EM, Gibson AG, et al. Stress-strain response modelling of glass fibre reinforced epoxy composite pipes under multiaxial loadings. Journal of Mechanical Engineering and Sciences. 2014;6:916-28.

[6] Santhanakrishnan G, Krishnamurthy R, Malhotra S. High speed steel tool wear studies in machining of glass-fibre-reinforced plastics. Wear. 1989;132:327-36.

[7] Jeffrey KJT, Tarlochan F, Rahman MM. Residual strength of chop strand mats glass fiber/epoxy composite structures: Effect of temperature and water 
absorption. International Journal of Automotive and Mechanical Engineering. 2011;4:504-19.

[8] Meenu, Kumar S. Optimization of the material removal rate in turning of UDGFRP using the particle swarm optimization technique. International Journal of Automotive and Mechanical Engineering. 2013;8:1226-41.

[9] Palanikumar K. Application of taguchi and response surface methodologies for surface roughness in machining glass fiber reinforced plastics by PCD tooling. The International Journal of Advanced Manufacturing Technology. 2008;36:1927.

[10] Koenig W, Wulf C, Grass P, Willerscheid H. Machining of fibre reinforced plastics. CIRP Annals-Manufacturing Technology. 1985;34:537-48.

[11] Aravindan S, Sait AN, Haq AN. A machinability study of GFRP pipes using statistical techniques. The International Journal of Advanced Manufacturing Technology. 2008;37:1069-81.

[12] Raj PP, Perumal AE, Ramu P. Prediction of surface roughness and delamination in end milling of GFRP using mathematical model and ann. 2012.

[13] Rajmohan T. Experimental investigation and optimization of machining parameters in drilling of fly ash-filled carbon fiber reinforced composites. Particulate Science and Technology. 2016:1-10.

[14] Kiran Varghese RKR, Sivarajan S. Optimisation of cutting parameters using Taguchi method in composite materials. International Journal of Scientific and Engineering Research. 2013;4:242-9.

[15] Hussain SA, Pandurangadu.V, kumar.K P. Multiple performance characteristic optimization in turning of GFRP composites using fuzzy logic. International Journal of Engineering Research International Journal of Engineering Research. 2014;3: 106-11.

[16] Hussain SA, Pandurangadu V, Kumar KP. Optimization of surface roughness in turning of GFRP composites using genetic algorithm. International Journal of Engineering, Science and Technology. 2014;6:49-57.

[17] Parida AK, Routara BC. Multiresponse optimization of process parameters in turning of GFRP using topsis method. International Scholarly Research Notices. 2014;2014, 905828, .

[18] Parida A, Bhuyan R, Routara B. Multiple characteristics optimization in machining of gfrp composites using grey relational analysis. International Journal of Industrial Engineering Computations. 2014;5:511-20.

[19] Kumar S, Meenu, Satsangi PS. Multiple performance optimization in machining of ud-gfrp composites by a PCD tool using distance-based Pareto genetic algorithm (DPGA). Mechanica Confab.2013; 2(2):49-66.

[20] Meenu, Kumar S. Prediction of surface roughness in turning of UD-GFRP using artifical neural network. Mech Confab. 2013;2:46-56.

[21] Raveendran P, Marimuthu P. Multi-response optimization of turning parameters for machining glass fiber-reinforced plastic composite rod. Advances in Mechanical Engineering. 2015;7:1687814015620109.

[22] Goswami A, Kumar J. Optimization in wire-cut EDM of Nimonic-80a using Taguchi's approach and utility concept. Engineering Science and Technology, an International Journal. 2014;17:236-46.

[23] Subrahmanyam S, Sarcar M. Evaluation of optimal parameters for machining with wire cut EDM using grey-Taguchi method. International Journal of Scientific and Research Publications. 2013;3:1-9. 
[24] Gupta M, Kumar S. Multi-objective optimization of cutting parameters in turning using grey relational analysis. International Journal of Industrial Engineering Computations. 2013;4:547-58.

[25] Goswami A, Kumar J. Investigation of surface integrity, material removal rate and wire wear ratio for WEDM of Nimonic 80a alloy using GRA and Taguchi method. Engineering Science and Technology, an International Journal. 2014;17:173-84.

[26] Goswami A, Kumar J. Trim cut machining and surface integrity analysis of Nimonic 80a alloy using wire cut EDM. Engineering Science and Technology, an International Journal. 2017;20:175-86.

[27] Kumar S, Meenu, Satsangi PS. Optimization of material turning operation-A state-of-art research review. International Journal of Scientific Research in Science, Engineering and Technology.2016;2(6):381-90.

[28] Ross PJ. Taguchi techniques for quality engineering: Loss function, orthogonal experiments, parameter and tolerance design. 1996. 